INTERNATIONAL JOURNAL OF SYSTEMATIC BACTERIOLOGY

Vol. 20, No. 4 October 1970

pp. $345-360$

\title{
THE PHYSICAL STRUCTURE OF THE CELL WALL AS A DIFFERENTIAL CHARACTER
}

\author{
FRANCIS L. A. BUCKMIRE $E^{1}$
}

Department of Bacteriology and Immunology University of Western Ontario, London, Canada

\section{INTRODUCTION}

The taxonomist has always relied heavily upon morphological criteria in characters to define groups at all levels. In this regard the bacterial taxonomist is no exception. He must rely on such things as size, shape, growth habits, motility, capsulation, sporulation and stain reactions, some of which in the bacterium are limited by the environment. This creates a real problem for the taxonomist since data obtained in an unnatural environment may give erroneous information regarding certain important and heavily weighted characters.

Among the more stable of the bacterial characters is the Gram reaction. Several hypotheses on the mechanism of this reaction have been proposed from time to time. Salton (1964) in an excellent review of the literature, has classified these hypotheses into two main groups:

(1) A Chemical Mechanism Based on the Possession of a Single Substance on Group of Chemical Substances Unique to the Gram-positive Bacteria.

Although many of the chemical constituents of the bacterial cell have been suggested as being involved in the Gram-positive reaction (Bartholomew, Cromwell and Finkelstein 1959; Burke and Barnes 1929; Deussen 1921; Dubos and MacLeod 1938; Eisenberg 1910; Henry and Stacey 1946; Henry, Stacey and Teece 1945; Kaplan and Kaplan 1933; Mitchell and Moyle 1958; Pointdexter and Cohen-Bazire 1964; Reyn, Lautrop and Birch-Anderson 1964; Salton 1963; Stearn and Stearn 1930; Webb 1948; Wensinck and Boevé 1957) so far no specific substance has been found to be responsible for it.

(2) A Permeability Difference between Gram-positive and Gramnegative Bacteria as the Basis of the Gram Reaction.

Salton (1964) favours this explanation and has suggested that the cell wall is not the site at which the crystal-violet and iodine used in the Gram stain form a complex but that it is the response of the cell wall to ethanol which results in a retention of this complex within the cell. He

\footnotetext{
$\Gamma$ A Medical Research Council of Canada Post-Doctoral Fellow (19671969).

The author wishes to express his sincere gratitude to Professor R.G. E. Murray, M.D. to whose laboratory he is now attached and to whom he is indebted for some of the work reported here on S. serpens. The author also wishes to thank Mrs. M. Hall and Mr. J. Marak for their expert photography and Mrs. O. Rattray for her general assistance.
} 
pointed out however, that more information about the physico-chemical nature of the wall was needed before a clearer picture can emerge and suggested it should then be possible to propose a detailed mechanism for the Gram reaction in terms of the chemistry of cell wall.

The unclear position of mechanism of the Gram reaction notwithstanding, it is significant that the different responses (positive and negative) of the bacterial cell to this reaction reflect themselves in the physical appearance of the bacterial cell wall when seen in profile. The cell wall also influences many of the characters(such as size, shape, etc.) usually considered as important in the classification of the bacteria.

\section{Classification of Cell Wall Profiles}

Generally speaking there is a considerable variation in the degree of differentiation and complexity in the bacterial cell envelope. These range from cells with no cell wall present, as in some L-forms (Hofschneider and Martin 1968), to cells with multilayers of cell wall (BirchAnderson, Maale and Sjostranc 1953; Chapman and Kroll 1957; Chapman and Hillier 1953; Costerton, Murray and Robinow 1961; Murray $1963 \mathrm{~b}$; Murray, Steed and Elson 1965; Ogura 1963; Weibull 1958). However, just as it is possible to divide bacteria into two main categories based on their Gram-reaction so is it possible to classify bacterial cell walls into two main groups based on their physical appearance in profile:

(I) The cell wall of Gram-positive bacteria.

(2) The cell wall of Gram-negative bacteria.

The Gram-positive Cell Wall Profile

I. In general the Gram-positive type of cell shows a relatively thick and homogeneous component situated next to the plasma membrane. This component is usually 150 to $800 \AA$ thick (Salton 1964). Figure 1 is an example of a typical Gram-positive organism Listeria monocytogenes.

There are, however, some variations within the Gram-positive type of cell wall. These can best be visualized by the use of different staining techniques, as Nermut and Murray (1967) have so elegantly demonstrated with Bacillus polymyxa. The cell wall profile of sections of this organism which were stained with such metal salts as uranyl acetate and lead citrate and subjected to different methods of post-staining revealed that the wall was not as homogeneous as previously believed but that it could be differentiated into layers. Figure 2 is an electron micrograph of a plasmolysed cell of Bacillus polymyxa in which three distinct cell wall layers are seen. Similar differentiation of the cell walls of some other Gram-positive bacteria when stained by a method similar to that used by Nermut and Murray have been reported also (Ghosh and Murray 1964).

Based on a combination of their differential staining technique and on cytochemical analyses of the walls, Nermut and Murray have proposed the following schematic diagram (Figure 3) of the cell wall of Bacillus polymyxa indicating the layers present and their possible chemical composition. The outermost layer which can be stripped off the cells by compounds capable of breaking hydrogen bonds, such as guanidine hydrochloride and sodium lauryl sulfate was considered to be protein. Underneath this layer was the intermediate layer of low density which was suggested to be polysaccharide. Situated between the layer of low density and the plasma membrane was a dense layer considered to be the mucopeptide. Although the picture of Gram-positive organisms possessing an 
outermost protein layer is certainly different from many earlier reports in which the vast majority of Gram-positive organisms were supposed to contain only a limited number of amino acids (Salton 1964), there is evidence that protein is present in the walls of some Gram-positive organisms other than Bacillus polymyxa. The cell walls of Bacillus subtilis for example, have been found to contain 7 to $10 \%$ of protein even though trypsin digestion was used in the preparation of the isolated walls (Janczura, Perkins and Rogers 1961). Also, the type specific M protein of Group A streptococci was detected in isolated cell wall preparations (Salton 1952). This protein along with other protein fractions were shown to overlay the polysaccharide layer containing the group specific carbohydrates which in turn overlays the mucopeptide (Krause 1963). The picture presented here for the cell wall of Bacillus polymyxa cannot be be considered to be typical of most Gram-positive bacteria since an examination of the cell wall of Bacillus megaterium (Nermut 1967), as well as many other Gram-positive bacteria by similar staining techniques to those of Nermut and Murray revealed only two layers. The missing layer was believed to be the protein layer (the outermost layer shown in the schematic diagram). In other cases only a thick single layer was present (Reyn, Birch-Anderson and Lapage 1966).

Despite the general similarities in the physical structures of the Grampositive bacterial cell wall, enzymatic digestion of the wall has led to the discovery that different degrees of susceptibility exist among the walls of even closely related organisms (McQuillen 1956, 1960; Weibull 1953). These differences presumably reflect differences in the chemical composition of the walls. Enzymatic digestion of some Gram-positive bacteria by lysozyme and other wall degrading enzymes result in complete dissolution of the wall and the formation of true protoplasts. With others the cells must first be exposed to another reagent prior to lysozyme digestion. This pattern of behaviour was found among different strairs of Listeria monocytogenes (Ghosh and Murray 1967). Certain strains of this organism were not affected by lysozyme alone; however, when the cells were first digested by lipase and then by lysozyme they readily became protoplasts. Short term ( 1 hour) lipase digestion as was normally used in protoplast formation caused no alteration in the cell wall structure although the cells stained Gram-negative (Ghosh and Murray 1967).

\section{The Gram - negative Cell Wall Profile}

II. In contrast to the profiles of the cell walls of Gram-positive bacteria, the profiles of the cell walls of Gram-negative bacteria are remarkably complex and consist of several obvious layers. Situated immediately outside the plasma membrane is a very thin electron dense layer-the mucopeptide (peptidoglycan). This layer which can be as thin as $20 \AA$ is common to both Gram-positive and Gram-negative (Janczura, Perkins and Rogers 1961; Murray 1960,1961; Murray, Steed and Elson 1965; Ogura 1963; Reyn, Birch-Anderson and Lapage 1966; Salton and Shafa 1958) and it is the layer of the cell wall most intimately connected with cell division. It forms a septum across the cell undergoing cell division thus dividing it into 2 daughter cells (Steed and Murray 1966). Outside this layer in the Gram-negatives is a "double-tracked" (electron dense, electron transparent, electron dense) layer of the order of $100-$ $200 \AA$ in thickness. This layer continues over the surface of the cell and is very plastic and appears to relax and separate during fixation process. 
In the last decade or so attempts to characterize chemically each layer seen in profile have been made with varying degree of success (Armstrong et al. 1958; Baddiley 1964; Bladen and Mergenhagen 1964; Salton and Shafa 1958; Weidel, Frank and Martin 1960). The biochemist has used different isolation procedures involving the use of chemicals and enzymes in an attempt to isolate specific wall components in the hope that this will lead to a better understanding of the cell wall structure. The bacterial anatomist on the other hand has attempted to analyse the effect of different isolation procedures on the various layers. As a result of some of these investigations several schematic diagrams relating the cell wall layers seen in the profile of Gram-negative bacteria to their chemical constituents have appeared recently (Baddiley 1964; Murray, Steed and Elson 1965; de Patris 1965). Figure 5 compares the models of Martin (1963) and Murray (Murray, Steed and Elson 1965). From the outside of the cells going inwards the cell is surrounded by a lipoprotein layer followed by a lipopolysaccharide layer. These two layers make up the so-called plastic portion of the cell wall. This is followed by the rigid layer which is composed of a continuous mucopeptide layer on whose outer surface, in some bacteria (notably Escherichia coli) (Martin 1966; Weidel, Frank and Martin 1960), are protein granules. The two models, though very similar in the order in which the different chemical constituents of the walls are arranged,are nevertheless different in the correlation of chemical constituents with the cell wall layers seen in thin sections. Martin believes that the outer double-tracked layer contains both the lipoprotein and the lipopolysaccharide while Murray suggests that the double-tracked layer is the lipopolysaccharide layer, with the lipoprotein layer (not visualized in sections) lying outside of it. Many other models attempting to correlate the physical appearance of the cell wall layers with its chemical makeup have also appeared recently (de Patris 1965; Tholey and Glauert 1968). Most of them agree that the rigid layer is situated next to the plasma membrane and to its outside are the lipoprotein and lipopolysaccharide fractions. Many do not agree, however, on the relative contribution of each of these fractions to the physical appearance of the cell wall as seen in profile. Recent accumulative information suggests that the lipopoly saccharide greatly contributes to the physical appearance of the outer double-tracked layer but that it is unlikely to be the only contributor.

An answer to this fascinating question may be provided by the recent work of MacLeod and co-workers (Buckmire and MacLeod 1965; Glauert 1962) on a marine Gram-negative pseudomonad.

The general profile of the cell wall of this organism (Figure 6) while typically Gram-negative in nature lacked the electron dense $20 \AA$ thick layer (generally regarded as the rigid layer) usually found in the vast majority of Gram-negative bacteria. MacLeod and co-workers (Forsberg, O'Leary and MacLeod, pers. comm.; Glauert 1962) have isolated in a highly purified state the outer double-tracked layer and they are now engaged in chemically characterizing it. When this layer was stripped off normal whole cells, intact rod-shaped cells enclosed in a single unit mernbrane (the plasma membrane) were left. Enzymatic digestion of these rods by lysozyme resulted in spherical forms still enclosed in the plasma membrane. Chemical analysis of the products of digestion revealed the presence of the mucopeptide components muramic acid and diaminopimelic acid. These results lend support to de Patris' view that 
the mucopeptide portion of the cell wall is not visualized in the normal cell (de Patris 1965). Similarly, convincing data in support of Martin and Murray's view that the rigid layer is the densely stained region which lies outside the plasma membrane have been presented by several authors (Bladen and Mergenhagers 1964; Claus and Roth 1964; Maier and Murray 1965; Weidel, Frank and Martin 1960; Weidel and Pelzer 1964). A possible explanation for the absence of the electron dense 'rigid' layer in marine bacteria may be that the mucopeptide of marine organisms, although chemically similar to that of terrestrial organisms is, nevertheless, quite different physico-chemically and as such is not as easily stained as its terrestrial counterpart by the stains now used for electron microscopy.

\section{Elaboration of the Basic Gram-negative Cell Wall Profile}

During the last few years improved techniques in the field of electron microscopy have led to the discovery of considerable structural complexity in the wall of Gram-negative species (Bayer and Anderson 1965; Chapman, Murray and Salton 1963; Cota-Robles 1963; Costerton, Murray and Robinow 1961; Maier and Murray 1965; Morita and Stave 1963; Murray 1963a, b; Murray and Watson 1963). Many of these complex structures are really elaborations of the basic Gram-negative cell wall profile and lie outside of it. These additions can be used as differentiating characters by which differences between closely related organisms can be distinguished. Unfortunately there are few comparative studies on the fine structure of closely related organisms from which one can obtain meaningful information about their family relationship.

Steed (1962) investigated the relationship which existed between Simonsiella crassa and Alysiella filiformis and suggested a family relationship (Simonsiellaceae) between them in the order Beggiatoales. Simonsiella

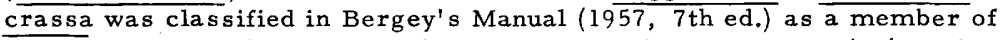
the family Caryophanaceae in the order Caryophanales. In 1967 (Steed-

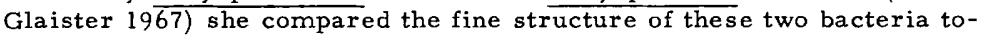
gether with that of another gliding bacterium (Lineola longa) which is classified in Bergey's Manual (1957, 7th ed.) as a member of the same family (Caryophanaceae) as Simonsiella crassa. Alysiella filiformis (Figure 7 ) consists of paired disc-shaped cells loosely as sociated as a filament. In profile the wall is typically Gram-negative with the outer double-tracked layer enclosing the constituent cell pair. In Simonsiella crassa (Figure 8) on the other hand, individual cells of a filament are more closely associated than the paired elements of Alysiella filiformis. The outer double-tracked layer, however, encloses the several cells within the filament. Lineola longa (Figure 9) also possess a multilayered wall. Unlike the others, however, its outer cell wall layer was homogeneous and of medium electron density (112 $\AA$ wide) and did not have the characteristic "electron dense-electron transparent-electron dense" profile so typical of other Gram-negative organisms. An electron transparent region separates the outer layer from a thick, electron dense element analogous to the rigid element of the wall profile of other organisms. The width of the dense layer is of the order of $110 \AA$, much greater than that of the thin, rigid element found in most Gram-negative bacteria. Another electron transparent zone lies adjacent to and outside of the plasma membrane. Analys is of the cell walls of this group of organisms show a high degree of similarity between Simonsiella crassa and Alysiella 
filiformis thus supporting the family relationship suggested by Steed (1962). Lineola longa does not belong to this group of organisms since its cell wall profile more closely resembles the Gram-positive.

Many authors (Lautrop, Reyn and Birch-Anderson 1964; Pate and Ordal 1967; Dworkin 1966; Voetz and Dworkin 1962) have examined the fine structure of another fascinating group of gliding bacteria- Myxobacteria-and have described them as typically Gram-negative in their wall profile. There were, however, certain interesting elaborations to the basic Gram-negative wall profile in Chondrococcus columnaris studied by Pate and Ordal (1967). This organism possesses peripheral fibrils which span the gap between the outer double-tracked membrane and the mucopeptide layer-a distance of about $100 \AA$. These fibrils run parallel to each other and along the length of the cell. Another interesting surface feature was the presence of a substance which coated the outer surface of the cell and which could be stained with the dye rutherium red. The authors speculated that the material was probably acid mucopolysaccharide.

The examples mentioned above demonstrate the type of simple variations of the basic Gram-negative wall one can expect among organisms. These are only a few of the many examples reported in the literature (Bladen and Mergenhagen 1964; Reyn, Birch-Anderson and Lapage 1966; Thornley and Glauert 1968) all of which would be too numerous to mention here.

There are, however, more complex elaborations of the basic Gramnegative wall. Many of these additions lie outside the outer doubletracked layer. The more extreme examples are those of Beggiatoales (Figure 10) and Thioploca ingrica reported in a comparative study of the two organisms by Maier and Murray (1965) and Lampropedia hyalina (Chapman and Kroll 1957) (Figure 11). The surface envelope of Lampropedia hyalina is particularly interesting and is an excellent example raf the complicated elaborations of the basic wall pattern that is possible in nature.

\section{Structural Surface Layers}

Not all the elaborations to the basic Gram-positive and Gram-negative cell wall profile are visualized by the routine staining techniques employed for the staining of thin sections. Many surface structures were first visualized by methods for observing surfaces under the electron microscope. In this regard techniques such as negative staining, metal shadowing and freeze etching have been particularly helpful. So far, interesting surface patterns have only been discovered on a relatively small number of organisms. Among the more classic ones are: Halobacterium halobium abserved by metal shadowing (Figure 12) (Houwink 1956; Stoeckenius and Rowen 1967). Acinetobacter species (by negative staining) (Figure 13) (Thornley and Glauert 1968), Spirillum serpens (by metal shadowing (Houwink 1953), negative staining and freeze etching, (Figures 14, 15, 16), Rhodospirillum rubrum (by metal shadowing) (Salton and Williams 1954), Lampropedia hyalina (by metal shadowing and negative staining) (Chapman, Murray and Salton 1963), Micrococcus radiodurans (by metal shadowing and negative staining)(Glauert 1966), Escherichia coli B (by negative staining) (Fischman and Seinbaun 1967), polymyxa (by metal shadowing and negative staining) (Figure 17) (McQuillen 1956). 


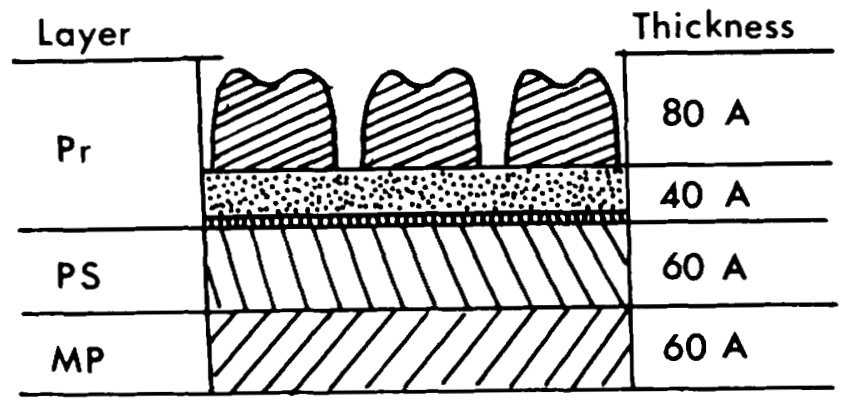

3

MARTINS MODEL

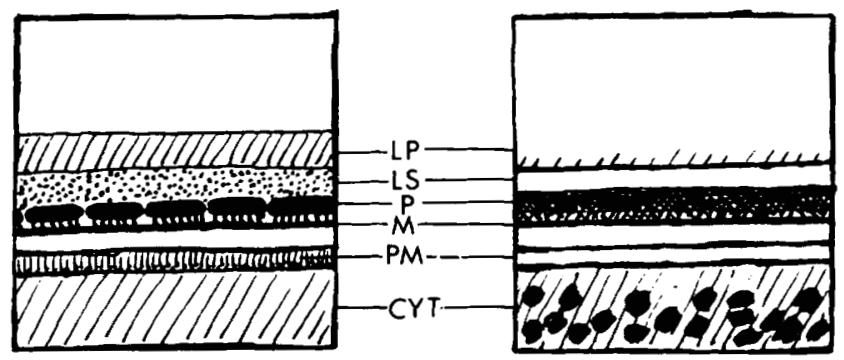

5

Figure 3. Schematic diagram of the cell wall layers seen in Bacillus polymyxa. (Nermut and Murray 1967).

Figure 5, Diagram illustrating Martin's and Murray's correlation of the Grarn-negative cell wall layers seen in section with what is known of the chemistry of the wall. (Martin 1963; Murray, Steed and Elson 1965). 


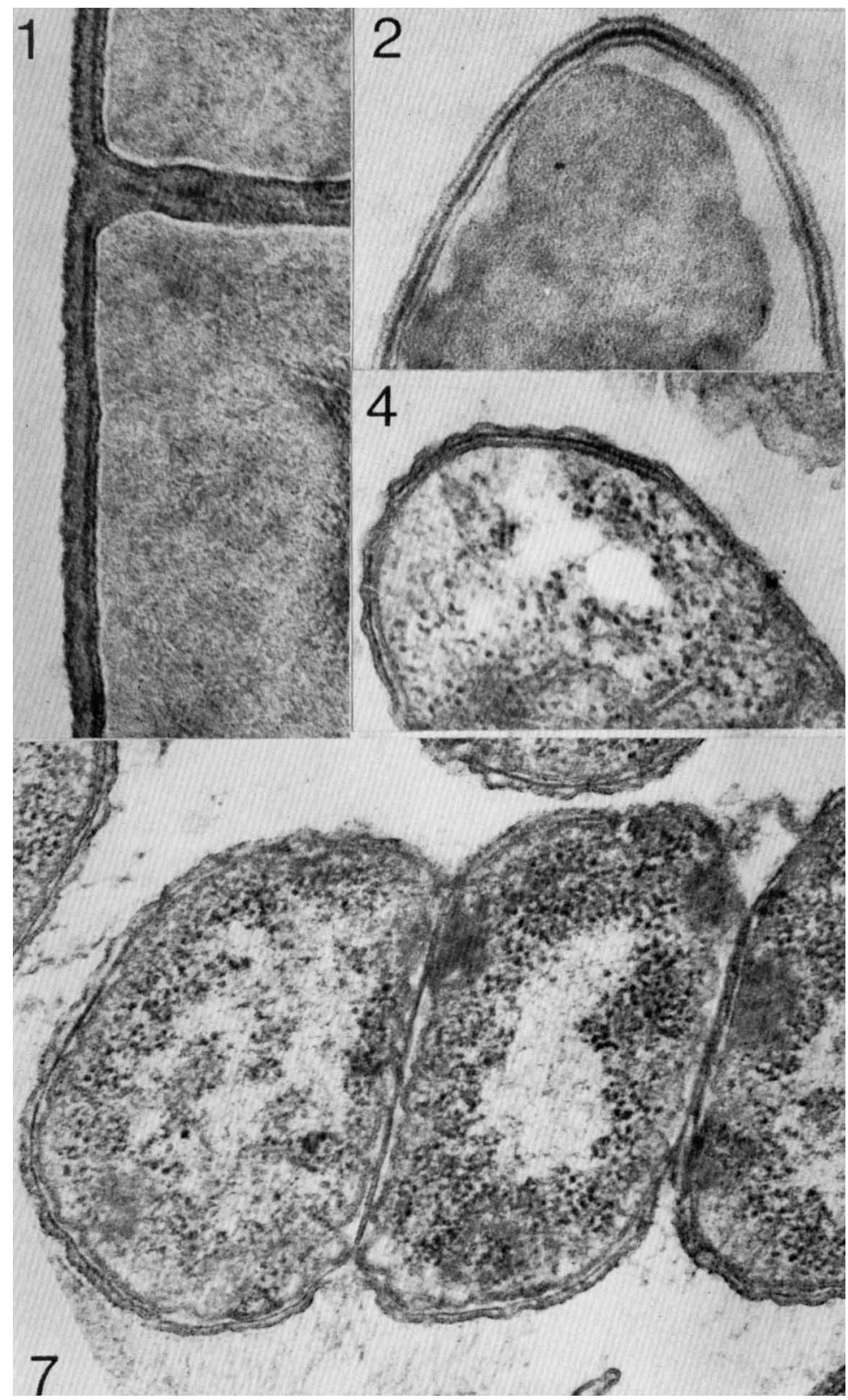

(See Legends, p. 356) 


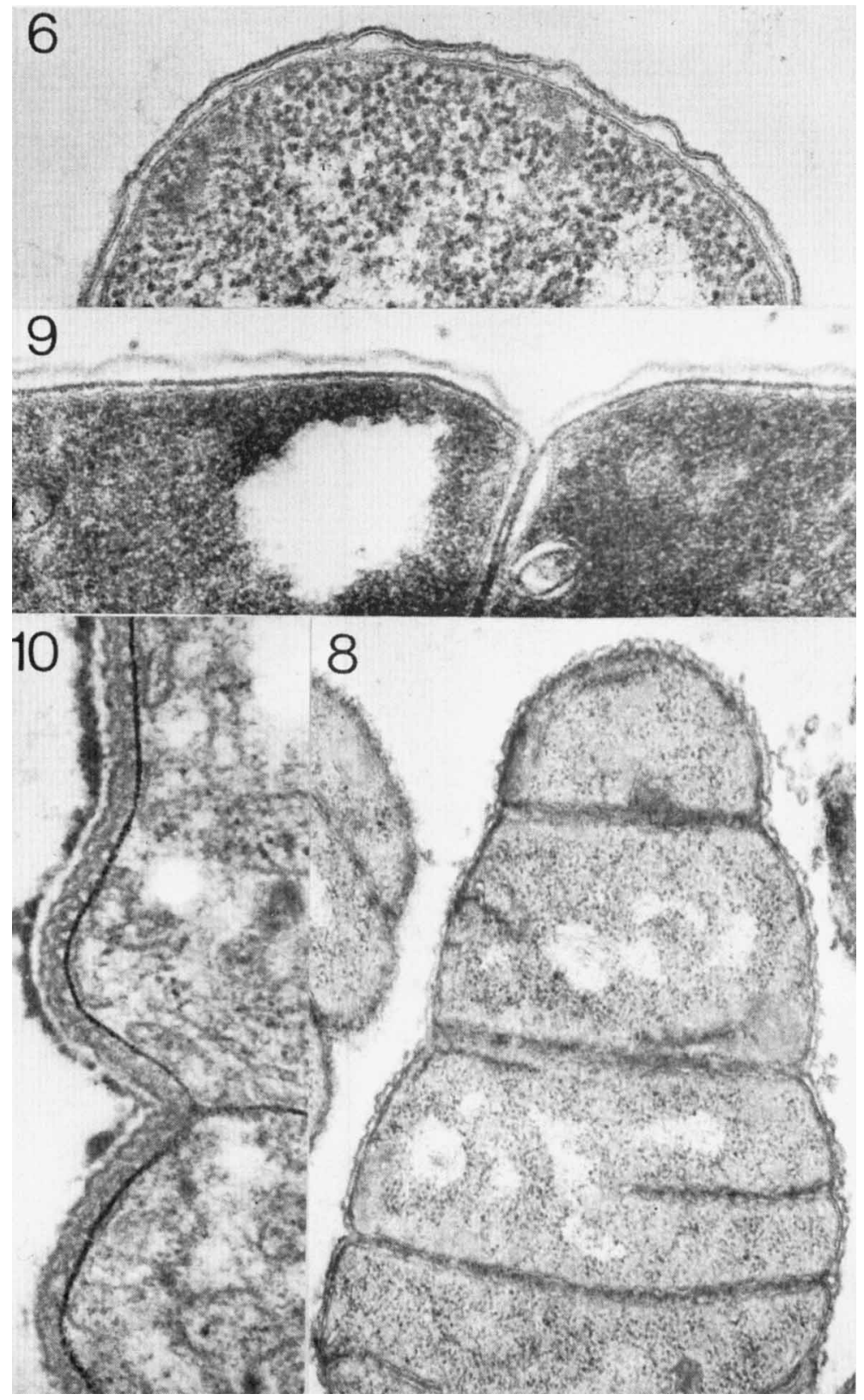

(See Legends, p. 356) 
INTERNATIONAL JOURNAL

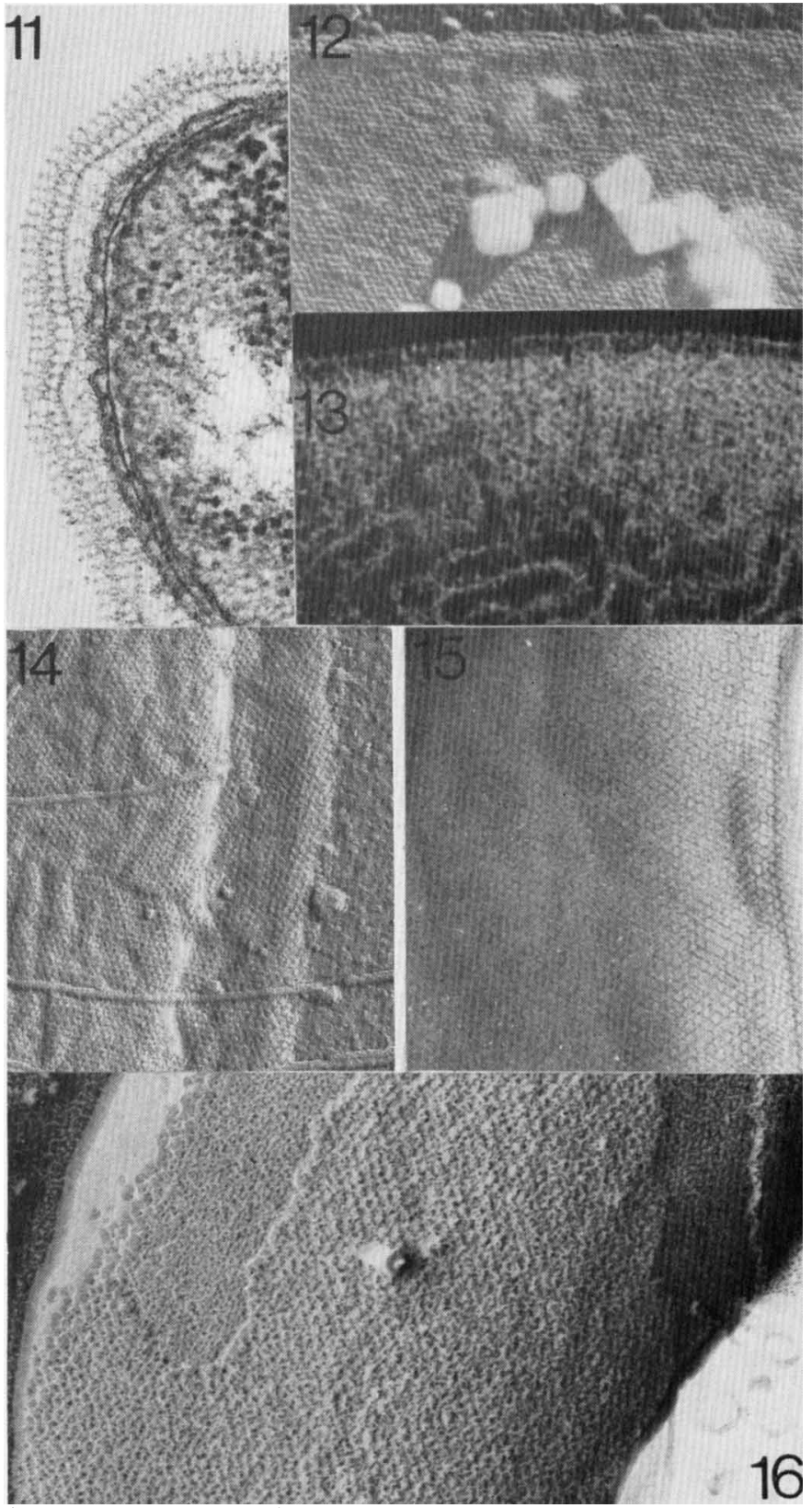

(See Legends, pp. 356-357) 


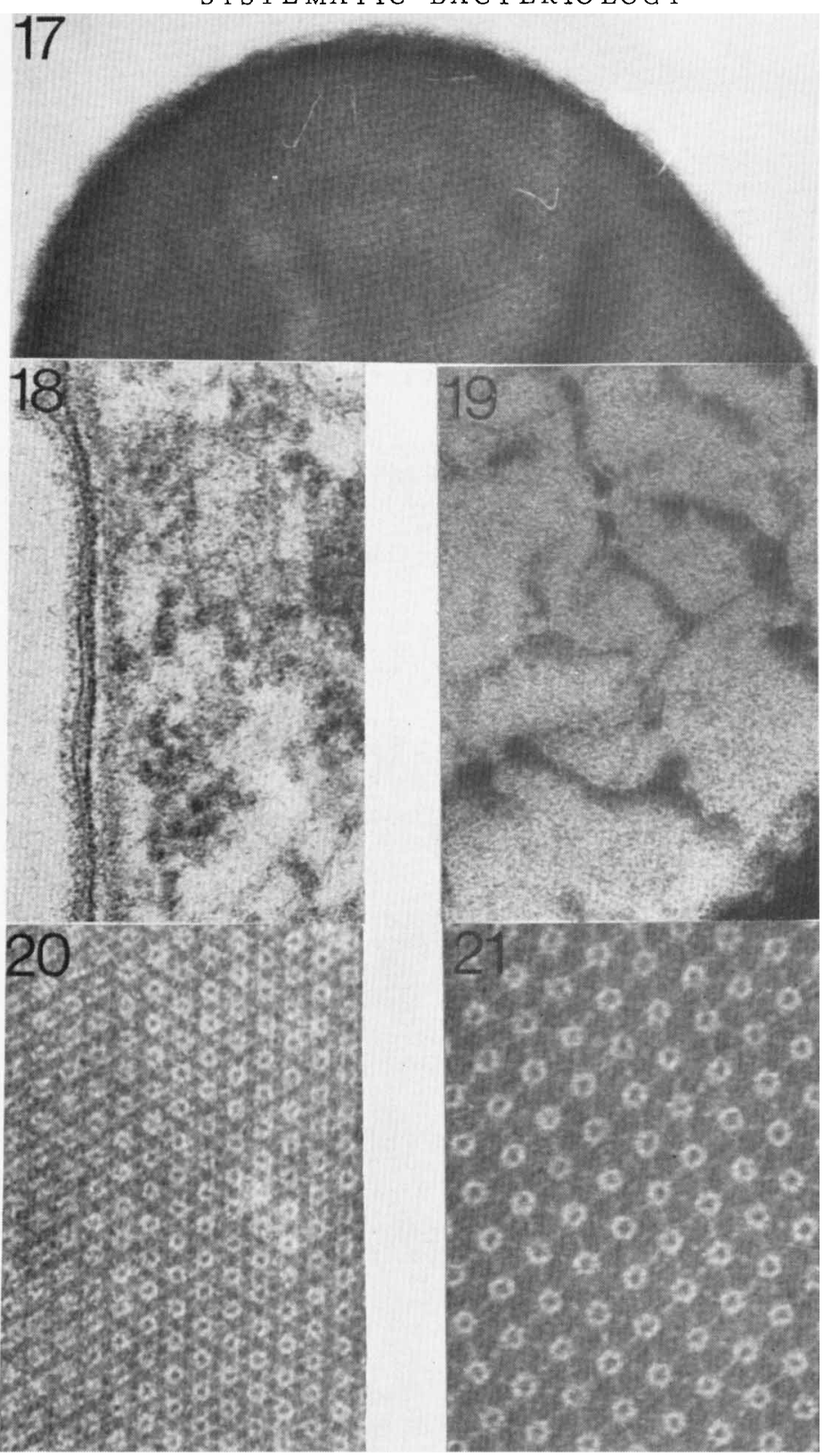

(See Legends, p. 357) 
Legends for Figures on preceding pages.

Figure 1. Example of Gram-positive (Listeria monocytogenes) cell wall in section: dense, homogeneous, thick structure situated next to the plasma membrane $(x 102,000)$. Electron micrograph from Ghosh and Murray (1967).

Figure 2. Example of cell wall layers seen in section in the Grampositive bacteria (Bacillus polymyxa). The cell is plasmolyzed. (x102, 000). Electron micrograph from Nermut and Murray (1967).

Figure 4. Example of Gram-negative (Spirillum serpens) cell wall in section: a loose outer "double-track" is situated above a thin, dense, rigid layer. $(x 74,000)$.

Figure 6. Section of a Gram-negative marine bacterium studied by MacLeod and co-workers (Buckmire and MacLeod 1965). Note the loose outer "double-track" layer and the absence of the thin, dense, rigid layer. There is also a very distinct electron transparent region separating the plasma membrane from the outer double-track layer. $(x 74,000)$.

Figure 7. Section of the Gram-negative Alysiella filiformis; the outer double-track layer encloses the constituent cell pair (x55, 000). (Micrograph from Steed-Glaister 1967).

Figure 8. Section of the Gram-negative Simonsiella crassa: the cells in filament are enclosed in the outer "double-track" $\overline{\text { layer }}(38,000)$. (Micrograph from Steed-Glaister 1967).

Figure 9. Section of the Gram-negative Lineola longa: the wall appears

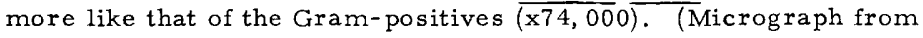
Steed-Glaister 1967).

Figure 10. Wall profile of Beggiatoa sp., showing its complexity and the inner, dense, rigid layer is the sole component of the cell wall septum (x55,000). (Micrograph from Maier and Murray 1965).

Figure 11. Wall profile of Lampropedia hyalina showing an elaborate outer structured layer. The structured complex layer lies outside the typical Gram-negative wall profile (x74,000). (Micrograph from Murray et al. 1963).

Figure 12. A shadowed preparation of the surface of Halobacterium halobium showing the presence of globular particles. (Micrograph from Stoeckenius and Rowen 1967).

Figure 13. A negatively-stained preparation of the structured surface of the Acinetobacter sp. studied by Thornley and Glauert (1968).

Figure 14. Shadowed preparation of the surface of Spirillum serpens strain VHA showing the presence of globular particles (protein). $(\times 52,000)$.

Figure 15. A negatively stained preparation (with sodium zirconium glycolate) of the surface of Spirillum serpens strain VHA showing the same particles as those shown in Figure 14. $(x 75,000)$. 
Figure 16. Freeze-etched preparation of Spirillum serpens strain VHA: a surface view of the outermost layer which contains the globular particles as well as the 'pitted' surface of an underlying layer are seen. $(\mathrm{x} 90,000)$.

Figure 17. A negatively stained preparation of the surface of Bacillus polymyxa showing its structured layer. (x102,000).

Figure 18. Wall profile of Spirillum serpens strain VHA showing a layer (the structured layer) external to the typical Gram-negative wall profile. $(x 130,000)$.

Figure 19. Negatively-stained preparation of Spirillum serpens strain VHL showing the absence of globular particles on its surface $(x 98,000)$.

Figure 20. Negatively-stained preparation of Spirillum serpens strain VHA showing the Y linkages which join the particles. (x211,000).

Figure 21. Negatively-stained preparation of Spirillum serpens strain MW6 showing the direct $(\Delta)$ linkages which join the particles $(x 285,000)$.

22

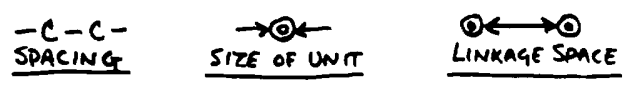

$\begin{array}{llll}\text { VHA } & 145-155 & \sim 90 & \sim 45 \\ \text { (Typicali } & & 35\end{array}$

$\begin{array}{llll}\text { MW 5 } & 145-155 & \sim 90 & 35-45 \\ \text { (atypical") } & & \\ \text { Mw 6 } & \sim 225 & 110-120 & \sim 100 \\ \text { (atypical") } & \sim 220\end{array}$

Figure 22. A schematic diagram of the types of linkages, the size of the globular particles and the distance (from centre to centre) between particles found on the surface of different strains of Spirillum serpens. 
Among the organisms mentioned above the one most widely investigated is Spirillum serpens by Murray and co-workers (Murray 1960/61; Murray 1963a, b; Murray, Steed and Elson 1965). This organism possesses on its surface an hexagonal array of particles. A detailed study of the arrangement of these particles was published by Murray (1963b). These particles which presumably constitute the outermost layer of the cell wall, were only seen in sections when special staining techniques were employed. When the organism was grown in a medium containing $\mathrm{Ca}^{++}$, and $\mathrm{Ca}^{++}$was added to every step of the dehydration process, this layer was clearly visible as seen in Figure 18. Under these conditions this external layer was approximately $70 \AA$ thick and the units in it had a periodicity of approximately $145-150 \AA$.

A survey of different strains of Spirillum serpens also revealed some remarkable surface differences between strains. Three different cell wall surface patterns were observed. Figure 19 is a negatively stained preparation of the surface of the bacterium showing the simplest of the surfaces. The particles are absent. Correspondingly, there is no addition to the basic Gram-negative cell wall. Figure 20 shows a negatively stained preparation of the structured layer. An orderly array of particles attached to each other by $\mathrm{Y}$-shaped linkages are seen. The particles are approximately $90 \AA$ in diameter with a centre to centre spacing of about 145 to $150 \AA$. Figure 21 also shows a similarly structured layer to the last figure but in this case the particles are attached to each other by direct linkages. Within this basic pattern there were two variations, Strain MW5, having particles of approximately $90 \AA$ in diameter and a

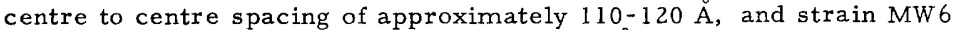
having particles of approximately 110 to $120 \AA$ in diameter and a centre to centre spacing of approximately $225 \AA$. Figure 22 is a diagrammatic presentation of the three structural variations observed on different strains of Spirillum serpens. This study thus illustrates how a detailed analysis of the cell surface variations present on different strains within a species can lead to the discovery of surface features which can differentiate between closely related organisms.

\section{CONCLUSION}

It is clear from the above that there are numerous examples of structural variation within the two basic cell wall categories. Many of these are so obvious that it is relatively easy to differentiate on the basis of their gross anatomy between organisms which are not closely related. In the case of closely related organisms it is not always easy to differentiate between them on the basis of gross morphology. Detailed examination of the fine structure of these organisms, however, has made it possible to distinguish between them on the basis of a few stable structural characters. In some of the se cases no difference in their normal physiology has been observed. It is obvious of course, that these small stable differences do reflect small differences in the biochemical make-up of the cell which the standard biochemical tests used for the purpose of classifying bacteria are unlikely to reveal. 


\section{REFERENCES}

Armstrong, J.J., J. Baddiley, J.Q. Buchanan, B. Carss and G. R. Greenberg. 1958. J. Chem. Soc., 4344

Baddiley, J. 1964. Endevour, 23:33.

Bartholomew, J.W., T. Cromwell and H. Finkelstein. 1959. Nature, $183: 123$.

Bayer, M.E. and T.F. Anderson. 1965. Proc. natn. Acad. Sci. U. S.A. 54:1592.

Bergey's Manual of Determinative Bacteriology. 1957. 7th ed. Ed. by R.S. Breed, E.G.D. Murray and N.R. Smith. Baltimore: Williams and Wilkins.

Birch-Anderson, A., O. Maale and F.S. Sjostrand. 1953. Biochim. biophys. Acta 12:395.

Bladen, H.A. and S. E. Mergenhagen. 1964. J. Bact. 88:1482.

Buckmire, F. L.A. and R.A. Macleod. 1965. Canad. J. Microbiol. $11: 677$.

Burke, V. and M.W. Barnes. 1929. J. Bact. 18:69.

Chapman, G.B. and A.J. Kroll. 1957. J. Bact, 73:63. and J. Hillier. 1953. J. Bact. 66:362.

Chapman, J.A., R.G.E. Murray and M.R.J. Salton. 1963. Proc. Roy. Soc., B. 158:398.

Claus, G.W. and L. E. Roth. 1964. J. Cell Biol. 20:217.

Costerton, J.W., C. Forsberg, T.I. Matula, F. L.A. Buckmire and R. A. MacLeod. 1967. J. Bact. 94:1764. $7: 329$ , R.G. E. Murray and C.F. Robinow. 1961. Canad. J. Microbiol.

Cota-Robles, E.H. 1963. J. Bact. 85:499.

Deussen, E. 1921. Z. Hyg. 93:512.

Dubos, R.J. and C.M. MacLeod. 1938. J. Exptl. Med. 67:791.

Dworkin, M. 1966. Ann. Rev. Microbiol. 20:75.

Eisenberg, P. 1910. Zent. Bakteriol. Parasitenk. 56:193.

Fischman, D.A. and G. Weinbaum. 1967. Science, N. Y. 155:472.

Forsberg, C., S. O'Leary and R.A. MacLeod. Personal Communication.

Ghosh, B.K. and R. G. E. Murray. 1967. J. Bacteriol. 93:411.

Glavert, A. M. 1966. J. Cell Sci. 1:425. - 1962. Brit. Med. Bull. $18: \overline{2} 45$.

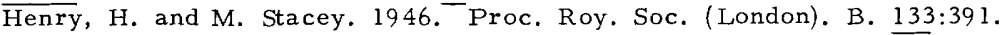
and E. G. Teece. 1945. Nature. 156:720.

Hofschneider, P.H. and H. H. Martin. 1968. J. gen. Microbiol. 51:23. Houwink, A. L. 1953. Biochim. Biophys. 10:360. - 1956. J. Gen. Microbiol. 15:146.

Janczura, E., H.R. Perkins and H.J. Rogers. 1961. Biochem. J. 80:82. Kaplan, M. L. and L. Kaplan. 1933. J. Bact. 25:309.

Krause, R. M. 1963. Bacteriol. Rev. 27:369.

Lautrop, H., A. Reyn and A. Birch-Anderson. 1964. Proc. 14th Scand. Congr. Pathol. and Microbiol. Universitets ferlaget, Oslo, 25-27 June. $157-160$.

Maier, S. and R.G.E. Murray. 1965. Canad. J. Microbiol. 11:645.

Martin, H. H. and H. Frank. 1962. Zentr. Bakteriol. Parasitenk. Abt.I Orig. 184:306.

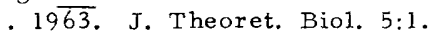
- 1966. Ann. Rev. Biochem. 35:457. 
McQuillen, K. 1956. Soc. Gen. Microbiol. Symposium No.6. 127. - 1960. The Bacteria, Eds. I. C. Qunsalus and R. Y. Stanier.

Vol. 1, Academic Press, Inc., New York, 250 pp.

Mitchell, P. and J. Moyle. 1958. Proc. Roy. Physic. Soc. (Edinburgh) 27:79.

Morita, R.Y. and P.W. Stave. 1963. J. Bact. 85:940.

Murray, R.G. E. 1960/61. In: Lectures on Theoretical and Applied

Aspects of Modern Microbiology. University of Maryland. - 1963a. Canad. J. Microbiol. 9:593.

- 1963b. Canad. J. Microbiol, $\overline{9}: 381$.

and S. W. Watson, 1963. Nature, London, 197:211.

, P. Steed and H. E. Elson. 1965. Canad. J. Microbiol. 11:547.

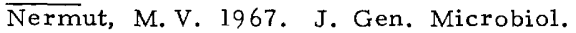
and R.G. E. Murray. 1967. J. Bact. 93:1949.

Ogura, M. 1963. J. Ultra struct. Res. 8:251.

Pate, J. L. and E. J. Ordal. 1967. J. Cell Biol. 35:37.

Patris, S. de. 1965. J. Ultrastruct, 12:247.

Pointdexter, J. L.S. and G. Cohen-Bazire. 1964. J. Cell Biol. 23:587.

Reyn, A., A. Birch-Anderson and S. P. Lapage. 1966. Canad. J. Microbiol. 12:1125.

, H. Lautrop and A.A. Birch-Anderson. 1964. Proc. XIV Scand.

Congr. Pathol. and Microbiol. Oslo: Universitets forlaget.

Salton, M.R.J. and R.C. Williams. 1954. Biochim. biophys. 14:455. - 1952. Biochem. Biophys. Acta 9:334.

- 1963. J. Gen. Microbiol. 30.

- 1964. Elsevier Publishing $\bar{C} 0 .$, Amsterdam.

and F. Shafa. 1958. Nature, London, 181:1321.

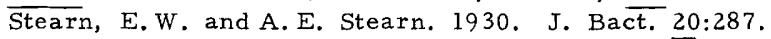

Steed, D. M. 1962. J. Gen. Microbiol. 29:615.

Steed, P. and R.G.E. Murray. 1966. Canad. J. Microbiol. 12:263.

Steed-Glaister, P.D. M. 1967. Ph. D. Dissertation, University of Western Ontario, London, Canada.

Stoeckenius, W. and R. Rowen. 1967. J. Cell Biol. 34:365.

Thornley, J. and A. M. Glauert. 1968. J. Cell Sci. $\overline{3: 273}$.

Voetz, H. and M. Dworkin. 1962. J. Bact. 84:84.

Webb, M. 1948. J. Gen. Microbiol. 2:260.

Weibull, D. 1958. Ann. Rev. Microbiol. 12:1.

Weibull, C. 1953. J. Bact. 66:688.

Weidel, W., H. Frank and H.H. Martin. 1960. J. Gen. Microbiol. 22: 158 .

and H. Pelzer. 1964. Advanc. Enzymol. 26:193.

Wensinck, F. and J. J. Boevé. 1957. J. Gen. Microbiol. 17:401. 